\title{
Estimating Direct Climate Impacts of End-of-Life Solar Photovoltaic Recovery
}

Michele Goe ${ }^{1}$ and Gabrielle Gaustad ${ }^{1, *}$

1 Golisano Institute for Sustainability, Rochester Institute of Technology, 190 Lomb Memorial Drive, Rochester, NY

*corresponding author: gabrielle.gaustad@rit.edu

\begin{abstract}
Resource recovery of end-of-life photovoltaics has been the focus of much recent research and development investment. Understanding the environmental impacts of collecting and processing these solar materials is imperative to informing the roll out of recycling infrastructure. This work combines traditional life-cycle assessment, geospatial statistical modelling, and processing optimization to quantify direct human and ecological impacts of PV resource recovery under a broad range of scenarios. For a baseline scenario, the most environmentally benign path is to landfill all of the end-of-life photovoltaics; this is due both to the sheer number and thereby close proximity of available landfill sites as well as the environmental burdens associated with current stateof-the-art recycling technologies. Such a disposal structure was found to be highly decentralized. Under a case where all materials are required to be recycled, emissions range from 7-252 grams $\mathrm{CO}_{2} \mathrm{eq} / \mathrm{kWh}$ depending on the region; highly distributed regions have equivalently larger environmental impacts. Credits for recycling decrease these impacts and make recycling more favorable for certain scenarios. Future processing facilities co-located near utility scale photovoltaic installations may make environmental sense assuming optimistic advancements in prospective resource recovery technologies.
\end{abstract}

Key words: Municipal solid waste; geo-spatial statistics; resource recovery; environmental impact; end-of-life; climate change

\section{Introduction}

Photovoltaic materials have been the focus of recent work on resource scarcity and material criticality[1,2]. The combination of limited material resources and rapid PV adoption has increased interest in recycling efforts. Indeed some efforts are underway to recover manufacturing scrap and end-of-life materials in Europe [3]. Recycling has been suggested to have benefits from an energy payback perspective[4,5]. Many recovery technologies are energy intensive and centralized waste collection systems currently in place often require long transport distances that potentially erode energy and emissions savings from recycling.

PV capacity has at least two different types: utility and distributed. Each type has its own unique challenges with regard to waste collection. Utility PV is typically a large installation of greater than $100 \mathrm{~kW}$. These installations are located on land areas as large as 1600 acres, such as the Solar Energy Generating Systems (SEGS) in California, and able to power 200,000 homes or more per day at peak power. The solar panels of utility PV are typically identical, bought directly from the manufacturer. Often in the case of utility PV, the manufacturer may even have knowledge about the performance and maintenance status of the installation. For this reason, previous scholars assumed that manufacturers could be responsible to take back their end-of-life panels for waste processing. However, in practice, utility solar panels are often sent through the municipal 
solid waste system as construction and demolition type waste. Distributed capacity is customer-sited solar panels. These installations are typically located on owner-occupied land or rooftops. Utility maintains the largest share of capacity (60\%) in the U.S. [6]. For utility installations, the large number of modules means waste from this source requires larger capacity vehicles or more trips to transport waste. Additionally, transfer stations, which are equipped to handle less than 10 tons of waste per day, may not have the capacity to store PV waste-in transit. In that case, utility scale waste would either be sent to multiple transfer stations or directly to landfill. Sending directly to landfill would reduce the transport distance while sending to multiple transfer stations would increase transport distance significantly.

Distributed or residential scale PV has its own unique challenges. Installations are often performed by third party contractors who buy panels from a diverse set of manufacturers. Owners often do not know what to do with panels that reach end-of-life due to becoming broken, weathered, or having decreased efficiency. Along the same lines as other emerging waste streams like consumer electronics, they are often put into storage as owners are reluctant to throw them out, but have scarce other options for disposal. There are almost no manufacturer based collection systems for recovering endof-life distributed PV panels.

Previous studies have assessed the potential of health and safety impacts of solar PV at end-of-life. In the production stage, thin-film CdTe was found to moderately expose workers to low levels of cadmium [7]. In the case of a fire, a small $(5 \mathrm{~kW})$ roof mounted installation was determined to present no potential health hazards [8]. There are also several studies that explore leaching of photovoltaic materials from landfills. Crushed thin-film modules have been shown to leach toxic metals such as cadmium and molybdenum $[9,10,11,12]$. This type of leachate could pose a potential threat to safe drinking water particularly in environments where acid rain is a concern [13], however the likelihood of panels being crushed to this degree under realistic conditions is likely low. There is a gap in the literature as to the long-term impacts of landfill leaching especially when multiple meteorological conditions (e.g. wind speed, temperature) are considered.

Recycling is often suggested to avoid negative human and environmental impacts of leaching. At least one solar manufacturer, FirstSolar, collects its utility scale installations for recycling in a highly controlled process [14]. However, producer takeback options are not available for residential solar applications. Previous work by the authors and others has shown that there is no economic incentive to collect end-of-life PV for recycling $[15,16]$. This means without legislative intervention, the majority of end-oflife solar modules will likely end up in the municipal solid waste stream.

Although several solar module life cycle impact assessments include landfilling they are typically non-specific about transportation network assumptions beyond distance. Other literature in the fields of operations research addresses the siting and location-allocation problem of traditional municipal solid waste with respect to environmental impacts [17,18,19,20,21,22]. Few studies address the direct social and environmental impacts of recycling, for example climate change related emissions, specifically with regards to solar photovoltaics recovery technology. There are no studies that explicitly investigate the environmental tradeoffs between waste transport distance, and recovery energy use. Further unexplored are the implications of changing module 
compositions, lifetimes, and geographic dispersion on end-of-life impacts. The material recovery in the context of municipal solid waste infrastructure in the US has not been studied. Given current literature gaps, we pose the following questions: what are the climate impacts of municipal solid waste photovoltaic recycling infrastructure on a regional scale? Where are the networks located? Which technologies should be employed? How does the optimal infrastructure change with increasing waste? This analysis seeks to address this gap in literature by exploring an end-of-life recovery infrastructure that utilizes the current municipal solid waste infrastructure with technology and land use modifications. Our objective is to investigate the potential environmental impacts from PV recovery infrastructure decisions on a regional level.

\section{Materials and Methods}

In order to address the aforementioned gap in literature, an environmental impact model was constructed that quantifies the carbon dioxide equivalent emissions per $\mathrm{kWh}$ from transportation (Section 2.1), landfill processing (Section 2.2), and recycling (Section 2.3) of end-of-life solar materials as shown in Figure 1. The model develops a list of all possible routes from solar installations to landfills. To reduce the spatial dispersion of installations, a group of many locations were modeled as one by geospatial clustering (Section 2.4). The transportation, landfill processing, and the recycling energy is calculated for each route. The total end-of-life energy is converted to carbon equivalent emissions. The model then determines a solution set of routes that minimizes the end-oflife emissions.

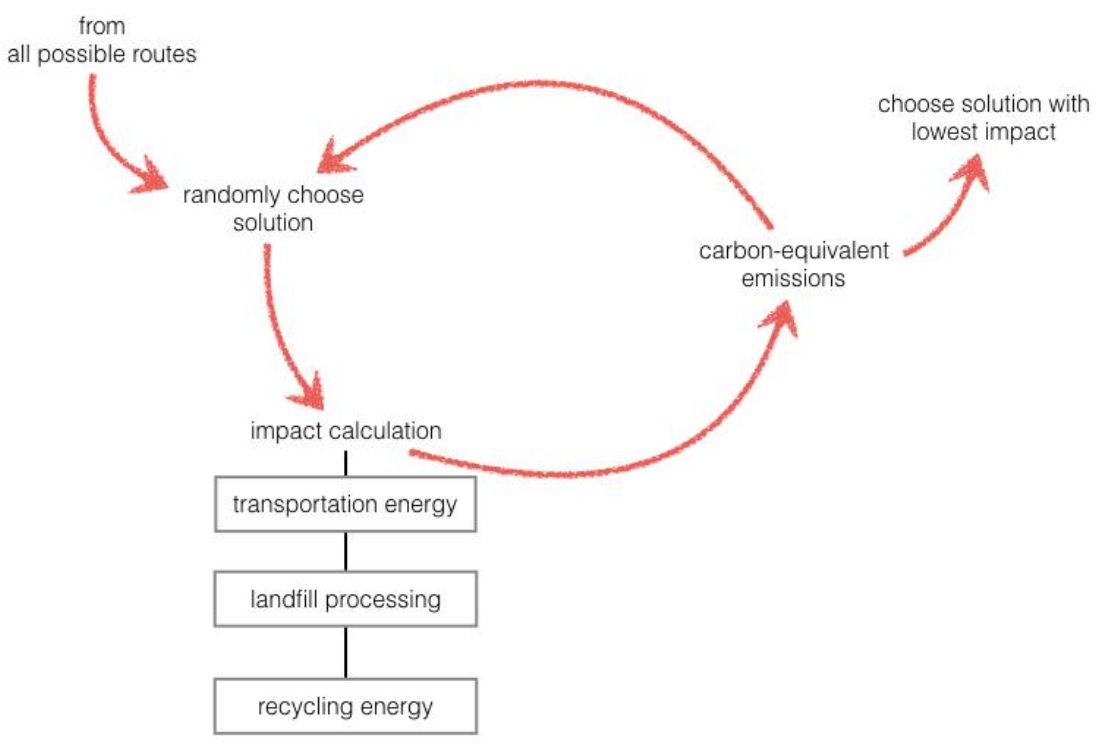


Fig. 1. Environmental Impact Model Algorithm

A list of all possible routes between solar installations and landfills was developed with a three-step algorithm. The first step requires the U.S. to be divided into regions where waste is traded to location-specific transfer stations and landfills. In the U.S., interstate trade of waste is prolific [23]. We use current interstate waste flow trends to delineate states into regions as shown in Table 4. A region is defined as a group of states that trade in more than half of their interstate municipal waste by mass as reported by McCarthy [23]. The second step is to group PV and landfills by region. We assume that solar PV waste can only be transported to any landfill within the same region where it is located. The last step is to generate a list of possible routes to a transfer station and landfill. Municipal solid waste (MSW) typically travels to a nearby transfer station before being sent to landfill. Following the MSW example, we assume solar PV is transported to the nearest regional transfer station en route to a landfill.

\subsection{Model Transportation Network Assumptions}

The network configuration is a static one period model. The time horizon for the model is sixty years; this time horizon is meant to match the lifetime of the average material recovery facility. Potential facility sites include material recovery facilities (MRFs) and active landfill sites in the study area. Based on previous work by the authors, cost based siting for a new PV recovery facility in the region will choose sites near current landfill and MRF facilities [16]. A list of landfills was obtained from the U.S. EPA database [24] was updated by exploring department of environmental conservation databases for each state if available. The updated list was then geocoded using Google API in R. Each recovery facility is assumed to have a co-located landfill. Therefore, once material is sent to a facility for recycling, no additional transport is required for landfill disposal. In the generalized model, every MRF can process and will accept all materials in a waste stream. In addition, each facility has capacity of 10 metric tons per day (TPD).

Transportation routes are the shortest distance round trip path on currently available road infrastructure between a PV installation and a material recovery facility. The number of trips between a given PV installation and landfill is determined by vehicle capacity. That is, the number of trips is equal to the quotient of the waste volume and vehicle capacity. Transportation energy is based on vehicle type, fuel type, and fuel economy. Vehicle emissions accounted for in this study include carbon dioxide $\left(\mathrm{CO}_{2}\right)$, dinitrogen oxide $\left(\mathrm{N}_{2} \mathrm{O}\right)$, and methane $\left(\mathrm{CH}_{4}\right)$. Impacts are reported as $\mathrm{kg} \mathrm{CO}_{2}$ equivalent per meter squared and $\mathrm{kg} \mathrm{CO} \mathrm{CO}_{2}$ equivalent per $\mathrm{kWh}$. In order to estimate truck capacity of PV modules, we use panel area and panel weight. Our vehicle emissions depends on the weight of the truck. The greater the weight of the modules the lower the fuel efficiency in ton-miles per gal. Each module is assumed to have an average peak power of $160 \mathrm{~W}$, panel area of $1.125 \mathrm{~m} 2$ and weight of $15.6 \mathrm{~kg}$. Peak power is important for determining how many modules are at each installation. For example if an installation has a total of $20 \mathrm{kWp}$ power we estimate this is approximately equal to 117 panels covering a 132 square meter area. These assumptions are based on average technical specifications from hundreds of 
panels [25]. To convert to $\mathrm{kWh}$ we assume modules have $20 \%$ efficiency, 0.8 performance ratio, and average sun hours of $5 \mathrm{kWh} / \mathrm{m} 2$ per day (average for U.S.) for a 30-year lifetime. We use silicon-based modules to model all installations because they have the largest share of the market.

The vehicle type and capacity for trips to the transfer station is uncertain. For the base case we assume all waste will be transported by a class 8a refuse/dump truck see Table 1 . This transport capacity is equivalent of up to $80 \mathrm{kWp}$ of panels per trip. To understand the sensitivity of our vehicle type assumption on the model output, multiple vehicle types were explored as shown in Table 1. For gasoline and diesel vehicles we assume heating value of 116,090 and 128,450 BTU per gallon respectively [26].

Table 1. Emission Factors and Fuel Economy by Fuel and Truck Type

\begin{tabular}{|c|c|c|c|c|c|c|c|}
\hline Class & $\begin{array}{l}\text { Vehicle } \\
\text { Application }\end{array}$ & $\begin{array}{l}\text { Max } \\
\text { Payload } \\
\text { Capacity } \\
\text { (lbs) }\end{array}$ & $\begin{array}{l}\text { Fuel } \\
\text { Economy } \\
\text { (ton-mpg) }\end{array}$ & $\begin{array}{l}\text { Fuel } \\
\text { type }\end{array}$ & $\begin{array}{l}\mathrm{CO} 2 \\
\text { (kg per } \\
\text { MMBTU) }\end{array}$ & $\begin{array}{l}\mathrm{N} 2 \mathrm{O} \\
(\mathrm{g} / \mathrm{km})\end{array}$ & $\begin{array}{l}\mathrm{CH} 4 \\
(\mathrm{~g} / \mathrm{km})\end{array}$ \\
\hline $1 \mathrm{t}$ & $\begin{array}{l}\text { Small } \\
\text { Pickup }\end{array}$ & $\begin{array}{ll}250 & - \\
1,500 & \end{array}$ & 17 & $\mathrm{G}$ & 19.54 & 0.0041 & 0.0101 \\
\hline $2 a$ & $\begin{array}{l}\text { Standard } \\
\text { Pickup }\end{array}$ & $\begin{array}{ll}250 & - \\
2,500 & \\
\end{array}$ & 26 & $\mathrm{G}$ & 19.54 & 0.0041 & 0.0101 \\
\hline $2 b$ & $\begin{array}{l}\text { Large } \\
\text { Pickup }\end{array}$ & 3,700 & 26 & $\mathrm{G}$ & 19.54 & 0.0041 & 0.0101 \\
\hline 4 & $\begin{array}{l}\text { City } \\
\text { Delivery }\end{array}$ & 7,250 & 42 & D & 22.37 & 0.0009 & 0.0006 \\
\hline 5 & $\begin{array}{l}\text { City } \\
\text { Delivery }\end{array}$ & 8,700 & 39 & $\mathrm{D}$ & 22.37 & 0.0009 & 0.0006 \\
\hline 7 & $\begin{array}{l}\text { Refuse/ } \\
\text { Dump }\end{array}$ & 18,500 & 55 & D & 22.37 & 0.030 & 0.0032 \\
\hline $8 a$ & $\begin{array}{l}\text { Refuse/ } \\
\text { Dump }\end{array}$ & $\begin{array}{l}20,000- \\
50,000\end{array}$ & 115 & $\mathrm{D}$ & 22.37 & 0.030 & 0.0032 \\
\hline
\end{tabular}

Notes: G - gasoline, D - diesel Source: [27,28]

\subsection{Material Availability and Recycling Energy Assumptions}

Material availability during the study period assumes total U.S. solar energy adoption of $538 \mathrm{GW}$ by 2075 . This future adoption estimate is based on the International Energy Agency (IEA) Solar Roadmap [29] which predicts the U.S. has $15 \%$ electricity power generation from solar energy by 2050 . This is aggressive considering the current share of solar powered electricity is $0.8 \%$ [30]. We extend the IEA scenario by assuming the U.S. maintains $15 \%$ solar powered electricity 60 years into the future. This allows for more gradual scaling-up of solar PV capacity at an average of $10 \mathrm{GW}$ per year. For comparison, the IEA 2050 scenario would require an increase of $36 \mathrm{GW}$ per year. The energy demand during this period for the U.S. and all other OECD countries remains unchanged [31]. 
Current solar PV adoption is dominated by silicon-based technologies at $90 \%$ market share. We assume all new solar installations are silicon-based with $20 \%$ efficiency and 0.80 performance ratio for ground and roof mounts. This is aligned with the bestavailable technology. Commercial silicon-based PV typically has an efficiency of $19 \%$ as compared to innovative silicon-based technologies that boost efficiencies as high as $24 \%$ [32]. The product lifetime of solar modules is based on module warranty of 70 percent power in 30 years. The locations of PV installations were determined from NREL database which provided latitude and longitude coordinates for approximately $30 \%$ of installed PV in the U.S. [33].

In order to quantify lifecycle end-of-life impact, we calculate the material recovery energy for landfill processing and exhaustive recycling. Landfill processing assumes modules are dismantled, shredded, and separated before being put in landfill. We estimate processing to be $0.34 \mathrm{MJ}$ per kg modules [34] similar to[35,36]. Exhaustive recycling assumes the mounts, frame, glass, and silicon-wafer components are recycled as shown in Figure 3. We assume recycling energy requirements and mass of materials as shown in Table 2. For this study, aluminum, glass, and steel recycling is equal to secondary embodied energy. The recycling energy requirements for silicon and thin-film cells are 30,288 MJ/m2 and 9,121-16,049 MJ/m2 respectively. These recycling processes yield $80-90 \%$ material recovery. The carbon equivalent emissions of recovery are calculated using the average state emission factors of electricity [37].

Whether to add recycling credits to a product is a debated topic in LCA literature recently explored by Frischknecht [38]. The LCA method of assigning credit for recycling is to account for the avoidance of burdens from primary material production. This method is sometimes known as the avoided burden approach. The avoided burden approach assigns recycling credits to the product that is recycled (after its use phase) regardless of whether it contains recycled material or not. The avoided burden approach implies that material flows in the economy are closed loop processes. However, for metals in general, and solar materials in particular, recycling rates are typically less than $35 \%$; so material flows are far from closed loop or $100 \%$ recycling rates. An alternative approach (taken in this paper) is known as the cutoff approach. The cutoff approach assigns the environmental burden to the secondary materials. The difference in the approaches is in the interpretation of allocation for LCA. Assigning recycling credits aligns with weak sustainability philosophy whereas the cutoff approach aligns more closely with strong sustainability. Using the avoided burden approach reveals that the impact of a recycling credit is dependent on assumptions about grid mix.

If the production grid mix is less favorable (higher carbon intensity) than the recycling grid mix we would expect a modest environmental benefit for recycling of between 0 - $20 \mathrm{~g} \mathrm{CO} 2$-equivalent per $\mathrm{kwh}$. This means recycling would reduce the environmental burden of the overall product lifecycle. In contrast, if the production grid mix for more favorable (lower carbon intensity) than the recycling grid mix we would expect to have a net environmental burden for recycling. Low carbon grid mix for production occurs if the primary materials are sourced from a country with high 
proportion of renewable electricity such as Germany. However, the majority of solar PV materials are produced and refined in relatively higher carbon electricity countries such as China and Japan, although several exceptions exist. As previously stated the magnitude of end-of-life emissions depends on the collection rate, recycling rate, recycling method, electricity emission factor of utility (state) and travel distance to recycling facility. Therefore a favorable end-of-life emissions scenario would likely involve less travel distance e.g. less than $500 \mathrm{~km}$, recycling at a facility with favorable grid mix such as California and lower recycling rates. Conversely an unfavorable end-oflife emissions scenario would involve longer distances e.g. more than $1000 \mathrm{~km}$, a recycling facility located where electricity emissions are carbon intensive e.g. New Jersey and higher recycling rate.

Table 2. Solar Module Material Recycling Energy and Mass Assumptions

\begin{tabular}{|l|l|l|}
\hline Material & Mass $(\mathrm{kg} / \mathrm{m} 2)$ & Recycling Energy \\
\hline Aluminum & $\begin{array}{l}\text { Frame } 0.14 \mathrm{~kg} / \mathrm{m} 2 \\
\text { Mounts } 1.7 \mathrm{~kg} / \mathrm{m} 2\end{array}$ & $31 \mathrm{MJ} / \mathrm{kg}$ \\
\hline Steel & $\begin{array}{l}\text { Roof } 197 \mathrm{~g} / \mathrm{m} 2 \\
\text { Ground } 2029 \mathrm{~g} / \mathrm{m} 2\end{array}$ & $10 \mathrm{MJ} / \mathrm{kg}$ \\
\hline Silicon + Glass & $1.125 \mathrm{~m} 2$ & $30,288 \mathrm{MJ} / \mathrm{m} 2$ \\
\hline
\end{tabular}

Source: [4,39]

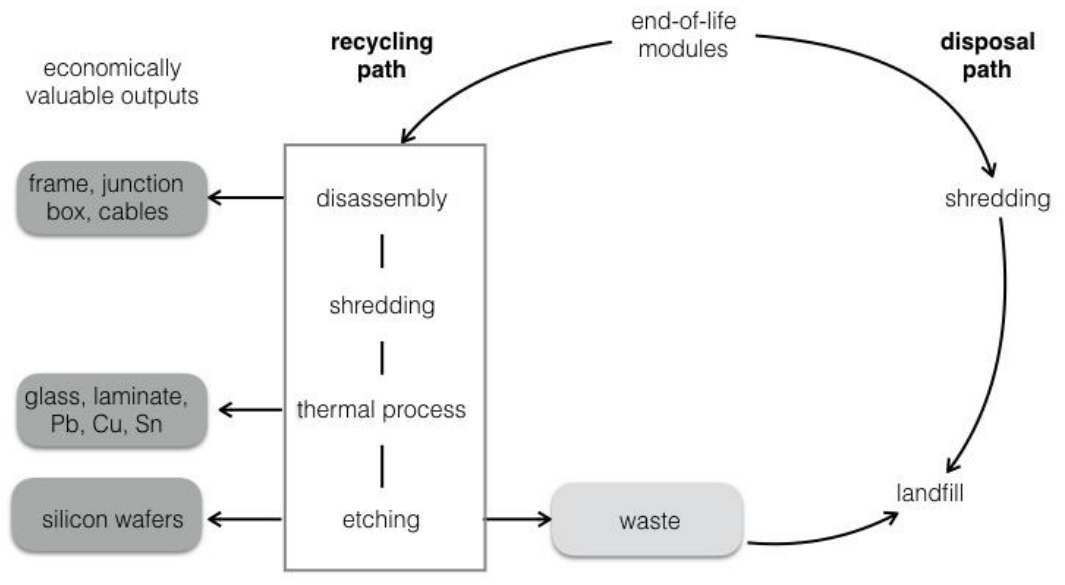


Figure 3. Recycling and Disposal Path Processes of End-of-Life Modules

\subsection{Environmental Impact Model.}

A recovery network model developed in [16] was adapted to determine the carbon equivalent emissions to the environment due to waste activities. The model was adopted by replacing economic costs with emission factors for each waste decision. The end-oflife waste decision considered in this study is the mass flow between the waste collection point, $i$, and the material recovery facility, $j$. The mass flow determines the emissions from recycling, transportation, and landfill processing. There are of course, other important impact categories to be considered for end-of-life recovery such as resource scarcity, metal depletion, eco-toxicity, and human health impacts [40,41]. These impacts will also have geo-spatial dependence and depend heavily on the optimal routes for endof-life. In order to include additional impact indicators alongside emissions, some valuation or prioritization of impacts needs to be assigned. In order to focus results on the tradeoffs between infrastructure decisions, the major impact category of greenhouse gas emissions was the focus here. Discussion of other impacts to be explored are included in the results.

The model's objective then is to organize the material recovery network in a way that minimizes the sum of these environmental impacts (equation 1). The material recovery network characterizes material flows of end-of-life solar panel materials from the waste source to a material recovery facility. This method implicitly selects the location of material recovery facilities and co-located landfills by allocating waste of mass greater than zero. If a material recovery facility has no waste allocated to it, it is assumed to be not a part of the recovery network. The choice of recovery technology choice for each material recovery facility is dependent upon scenario assumptions.

In this model there are $I$ customers with end-of-life PV available for collection. Each customer can be routed to $J$ potential material recovery facility (MRFs) locations. Each MRF has a capacity $z_{j}$ and an electricity emission factor $f_{j}$. The modeler specifies the recovery rate $\gamma_{r}$ and the associated energy rate per $\mathrm{kWh}, e_{r}$. We are interested in $X_{i j}$ the $\mathrm{kWh}$ of EoL PV and $t_{i j}$ the distance materials are transported from customer $i$ to MRF $j$. The emission factor for the route distance is $e_{t}$. Material that is disposed of, $U_{i}$ is subject to landfill processing emissions, $e_{d}$. In this formulation the objective is to minimize the environmental impact of the material recovery network. This objective (equation 1) is subject to constraints of mass balance (equation 2-3), facility \& technology opening conditions (equations 4-5), capacity constraints (equation 6), and non-negativity (equation 7). This formulation is general and can reflect many different recovery scenarios. For example, we can model mandatory collection by setting the environmental impact of disposal $e_{d}$ to an extremely high or infinite value. We can also simulate a distributed or centralized system by setting $\sum_{j \in J} \quad Y_{j}>1$ or $j=1$ respectively. This particular formulation does not grant a credit for recycling as discussed previously as the goal is a comparative assessment of impacts from geo-spatially optimal recovery infrastructures. Implications of this assumption are discussed further in the results.

$$
\min \sum_{j \in J} \sum_{k \in K}\left(\sum_{i \in I} X_{i j}\right) e_{r} f_{j} Y_{j}\left(\gamma_{r}\right)+\sum_{i \in I} \sum_{j \in J} e_{t} t_{i j} X_{i j}+\sum_{i \in I} e_{d} U_{i}
$$




$$
\begin{gathered}
\sum_{j \in J} X_{i j}-r_{i}=U_{i} \quad \forall i \in I \quad \text { [ Equ. 2] } \\
r_{i}=\sum_{j \in J} \quad X_{i j} Y_{j}\left(1-\gamma_{r}\right) \quad \forall i \in I \text { [Equ. 3] } \\
\sum_{i \in I} \quad X_{i j} \leq Y_{j} \quad \forall j \in J \text { [Equ. 4] } \\
Y_{j} \in\{0,1\} \quad \forall j \in J, \forall k \in K \text { [Equ. 5] } \\
\sum_{i \in I} X_{i j} Y_{j} \leq Z_{j} \quad \forall j \in J \text { [Equ. 6] } \\
X_{i j}, Y_{j k}, Y_{j} \quad \forall i \in I, \forall j \in J, \forall k \in K \text { [Equ. 7] }
\end{gathered}
$$

[Equ. 1]

\subsection{Geographic Clustering Mapping}

Previous research suggests that solar PV installations geographically cluster based on demographics or influences from peers or community organizations [42,43,44]. Various methods can be used to determine the degree of clustering such as comparing the proximity between events as compared to randomly dispersed set of events. Generalizing clusters of events is one method to identify spatial patterns. We clustered PV installations using a k-nearest neighbor cluster method so that many points would be modeled as one demand point with the capacity equal to the sum of the clustered points. This method uses least square of the Euclidean distance to identify clusters. Least squares with geographic coordinates skews the clusters towards higher density locations. Which means a large number of closely located points will likely be categorized as one cluster similar to a small number of sparsely located points. The result is that sparse points are lumped together. The largest consequence is accuracy of distance measurement. To remedy this we have increased the number of clusters to reduce the mean distance between the cluster point and any waste collection to under $50 \mathrm{~km}$. Since we have defined a trip as the direct route between a MRF and a waste collection point the minimum number of trips for each clustered point is equal to the number of waste collection points.

Clustering implicitly develops zoning structure where a group of EoL installations are processed at the same facility. A benefit to zoning would be that installers and MRFs have incentive to collect information about current adoption trends in their allocated zone. However, without zoning MRFs would be "free" to accept materials on a technology basis from any location.

3. Results and Discussion

Our estimates of future PV adoption are based on current policies and trends. Several U.S. states have policies that encourage distributed generation such as net metering, grants or loan programs, tax credits and property tax incentives. The southwest states of region 1, California, Nevada, Utah, Colorado, New Mexico and Arizona have the highest combined utility capacity than any other region of the U.S, see Figure 4. The MidAtlantic region: New York State, Pennsylvania and New Jersey, have the second largest combined number of PV installations and capacity. The mid-atlantic states are among the most important financially given high GDP per capita, population densities, and electric power demands. Previous environmental impacts studies have suggested Mid-Atlantic 
States may best benefit from higher solar PV adoption despite lower annual sun hours than southwestern states due to their current reliance on coal-fired power plants for electricity [45].

We use current interstate waste flow trends to delineate states into regions as shown in Table 3. The dispersion and capacity of PV for each state and region is unique. For example, region 1 has the most sun-hours and over $60 \%$ of total U.S. solar capacity. Region 5 has the least sun-hours, and PV is highly dispersed. Despite major differences, there are many similarities between regions. In all regions, approximately half of installations are greater than $1 \mathrm{MW}$. We refer to those installations with greater than 1 MW capacity as "utility". In region 5 the majority of installations are less than 10kW (referred to as distributed). In several region 1 states, the majority of installations are distributed. This means PV is installed on owner-occupied land or rooftops, yet its capacity is large enough to supply year-around electricity for a home. Distributed is very popular in less densely populated states (e.g. Idaho, Oklahoma, Montana, Nebraska). Distributed installations are also found in large proportion of states with robust economic incentives such as net metering, renewable portfolio standards with solar provisions, and/or rebate programs (e.g. California, New York, Massachusetts).

Table 3. U.S. States Divided by Interstate Municipal Waste Flows

\begin{tabular}{|l|l|l|l|}
\hline $\begin{array}{l}\text { Region } \\
\text { No. }\end{array}$ & $\begin{array}{l}\text { Description of } \\
\text { Solar PV }\end{array}$ & States & $\begin{array}{l}\text { Land } \\
\text { Area } \\
\text { Thousan } \\
\text { d square } \\
\text { miles) }\end{array}$ \\
\hline 1 & $\begin{array}{l}\text { High-density } \\
\text { Large share } \\
\text { capacity } \\
\text { Large share utility } \\
\text { High sun hours }\end{array}$ & $\begin{array}{l}\text { Arkansas (AR), Oregon (OR), } \\
\text { Washington (WA), Idaho (ID), Louisiana } \\
\text { (LA), Wyoming (WY), Montana (MO), } \\
\text { Arizona (AZ), New Mexico (NM), Texas } \\
\text { (TX), Oklahoma (OK), Kansas (KS), } \\
\text { Nevada (NV), Utah (UT), Colorado (CO), } \\
\text { California (CA), Nebraska (NE), Montana } \\
\text { (MT) }\end{array}$ & 1856 \\
\hline 2 & $\begin{array}{l}\text { High dispersion } \\
\text { Low sun hours }\end{array}$ & $\begin{array}{l}\text { Iowa (IA), Illinois (IL), Connecticut (CT), } \\
\text { South Dakota (SD), New York (NY), New } \\
\text { Jersey (NJ), Indiana (IN), Wisconsin } \\
\text { (WI), West Virginia (WV), North Dakota } \\
\text { (ND), Minnesota (MN), Michigan (MI), } \\
\text { Kentucky (KY), Ohio (OH), Pennsylvania } \\
\text { (PA), Tennessee (TN), Mississippi (MS) }\end{array}$ & \\
& $\begin{array}{l}\text { Rhode Island (RI), Georgia (GA), South } \\
\text { Carolina (SC), Tennessee (TN), } \\
\text { Mississippi (MS), Alabama (AL), South } \\
\text { Carolina (SC), Florida (FL), North } \\
\text { Carolina (NC), Massachusetts (MA) }\end{array}$ & 383 \\
\hline 3 & $\begin{array}{l}\text { High utility } \\
\text { High dispersion sun hours }\end{array}$ & & \\
& High & \\
\hline
\end{tabular}




\begin{tabular}{|l|l|l|l|}
\hline 4 & $\begin{array}{l}\text { High density } \\
\text { High Utility } \\
\text { Low sun hours }\end{array}$ & $\begin{array}{l}\text { District of Columbia (DC), Virginia (VA), } \\
\text { Delaware (DE), Maryland (MD) }\end{array}$ & 53 \\
\hline 5 & $\begin{array}{l}\text { Highly dispersed } \\
\text { High Residential } \\
\text { Low Utility } \\
\text { Low sun hours }\end{array}$ & $\begin{array}{l}\text { Vermont (VT), New Hampshire (NH), } \\
\text { Maine (ME) }\end{array}$ & 52 \\
\hline
\end{tabular}

The distance between installations is one measure of the density of PV. Distributed PV tends to clusters in mid to large cities. For example, $40 \%$ of PV in Northern California is sited in or near Sacramento, Oakland, San Francisco, and San Jose. Utility installations are typically located in remote regions, more than $10 \mathrm{~km}$ away from the nearest utility installation as shown in Table 4. These low utility states have highly dispersed installations with an average distance of $10 \mathrm{~km}$ between the next nearest installation.

Table 4. PV Density Measurement: Nearest Utility and Distributed Installations by Region

\begin{tabular}{|l|l|l|l|l|l|l|}
\hline & & $\mathrm{R} 1$ & $\mathrm{R} 2$ & $\mathrm{R} 3$ & $\mathrm{R} 4$ & $\mathrm{R} 5$ \\
\hline $\begin{array}{l}\text { Nearest } \\
\text { Utility }\end{array}$ & $\begin{array}{l}\text { Average } \\
\text { Distance (km) }\end{array}$ & 13,586 & 14,155 & 23,049 & 15,856 & 27,841 \\
\cline { 2 - 7 } & $\begin{array}{l}\text { Percent more than } \\
10 \text { km away }\end{array}$ & 51 & 60 & 70 & 92 & 100 \\
\hline $\begin{array}{l}\text { Nearest } \\
\text { Residential }\end{array}$ & $\begin{array}{l}\text { Average } \\
\text { Distance (km) }\end{array}$ & 571 & 1,963 & 720 & 1,366 & 1,178 \\
\cline { 2 - 7 } & $\begin{array}{l}\text { Percent less than 1 } \\
\text { km away }\end{array}$ & 94 & 85 & 90 & 80 & 65 \\
\hline
\end{tabular}




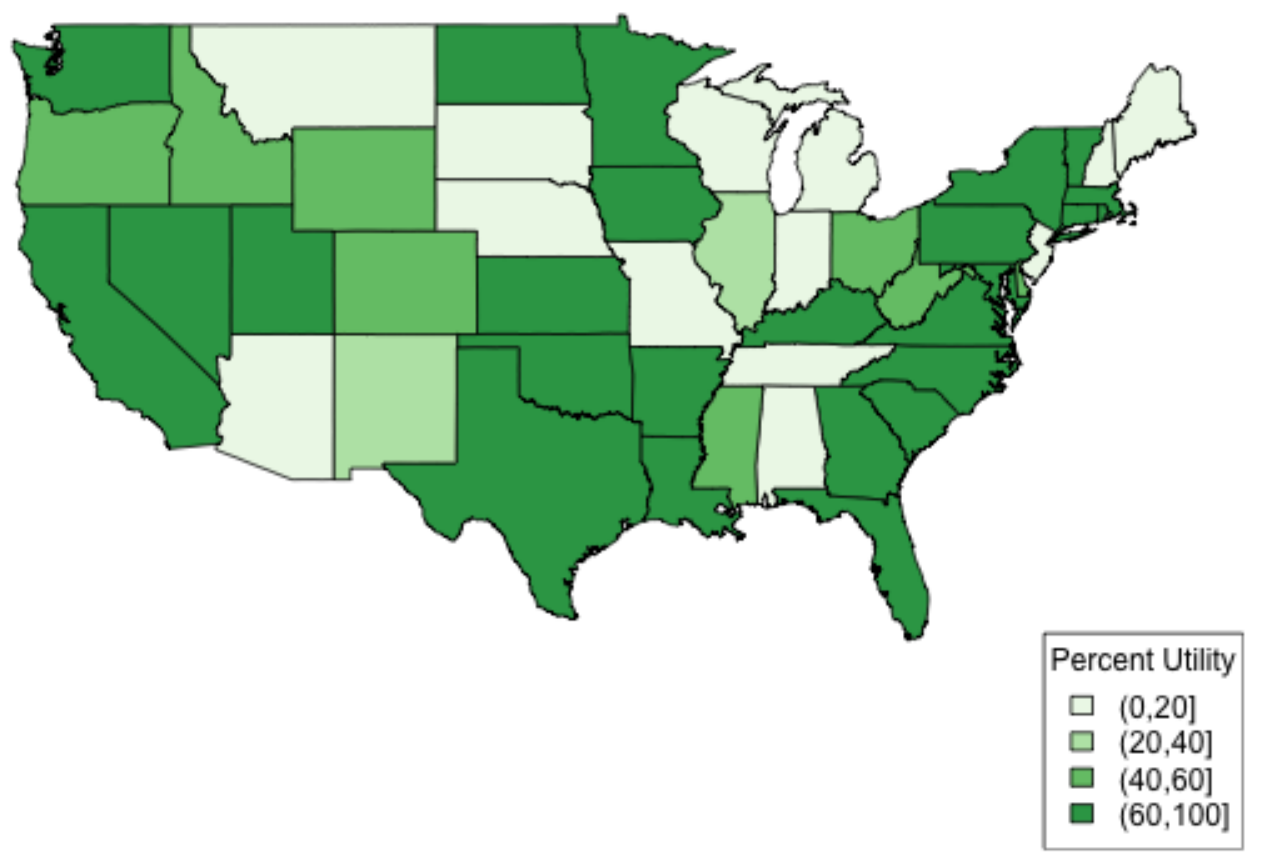

Figure 4: Share of Solar Capacity Greater than $1 \mathrm{MW}$ (Utility) by State

\subsection{Waste Transportation Network Impacts}

Each region is characterized by over 100 landfills sites, many of which are less than $5 \mathrm{~km}$ from one another. Therefore, we selected the ten most dispersed facilities to include in our analysis. Of these, in any particular region the next nearest landfill is greater than 20 km away.

Table 5. Count and Capacity Share of Installations by Size and Region

\begin{tabular}{|l|l|l|l|l|l|}
\hline Category & Region 1 & Region 2 & Region 3 & Region 4 & Region 5 \\
\hline Utility (> 1 MW) & $48.2 \%$ & $44.2 \%$ & $53.0 \%$ & $46.9 \%$ & $52.5 \%$ \\
\hline $\begin{array}{l}\text { Mean (kW) per } \\
\text { Installation }\end{array}$ & 19.9 & 37.7 & 38.2 & 25.4 & 17.8 \\
\hline $\begin{array}{l}\text { Largest Installation } \\
\text { Capacity (MW) }\end{array}$ & 333 & 3.8 & 27.6 & 17.7 & 2.9 \\
\hline $\begin{array}{l}\text { Share of U.S. } \\
\text { Installations }\end{array}$ & $74.8 \%$ & $16.6 \%$ & $4.8 \%$ & $2.9 \%$ & $1.0 \%$ \\
\hline
\end{tabular}




\begin{tabular}{|l|l|l|l|l|l|}
\hline $\begin{array}{l}\text { Share of U.S. } \\
\text { Capacity }\end{array}$ & $62.3 \%$ & $26.2 \%$ & $7.7 \%$ & $3.1 \%$ & $0.7 \%$ \\
\hline
\end{tabular}

Table 6 One-Way Average Distance Between Installation, Transfer Station, and Landfill Along Route

\begin{tabular}{|l|l|l|l|l|l|l|}
\hline All km & & $\begin{array}{l}\text { Region } \\
1\end{array}$ & $\begin{array}{l}\text { Region } \\
2\end{array}$ & $\begin{array}{l}\text { Region } \\
3\end{array}$ & Region 4 & Region 5 \\
\hline $\begin{array}{l}\text { Installation } \\
\text { to Transfer } \\
\text { Station }\end{array}$ & Utility & 98 & 30.3 & 80.5 & 16.9 & 30.1 \\
\cline { 2 - 7 } & Distributed & 34.3 & 32.3 & 55.9 & 10.3 & 17.1 \\
\hline $\begin{array}{l}\text { Transfer } \\
\begin{array}{l}\text { Station to } \\
\text { Landfill }\end{array}\end{array}$ & All & 13.8 & 1.0 & 11.7 & 2.6 & 6.7 \\
\hline
\end{tabular}

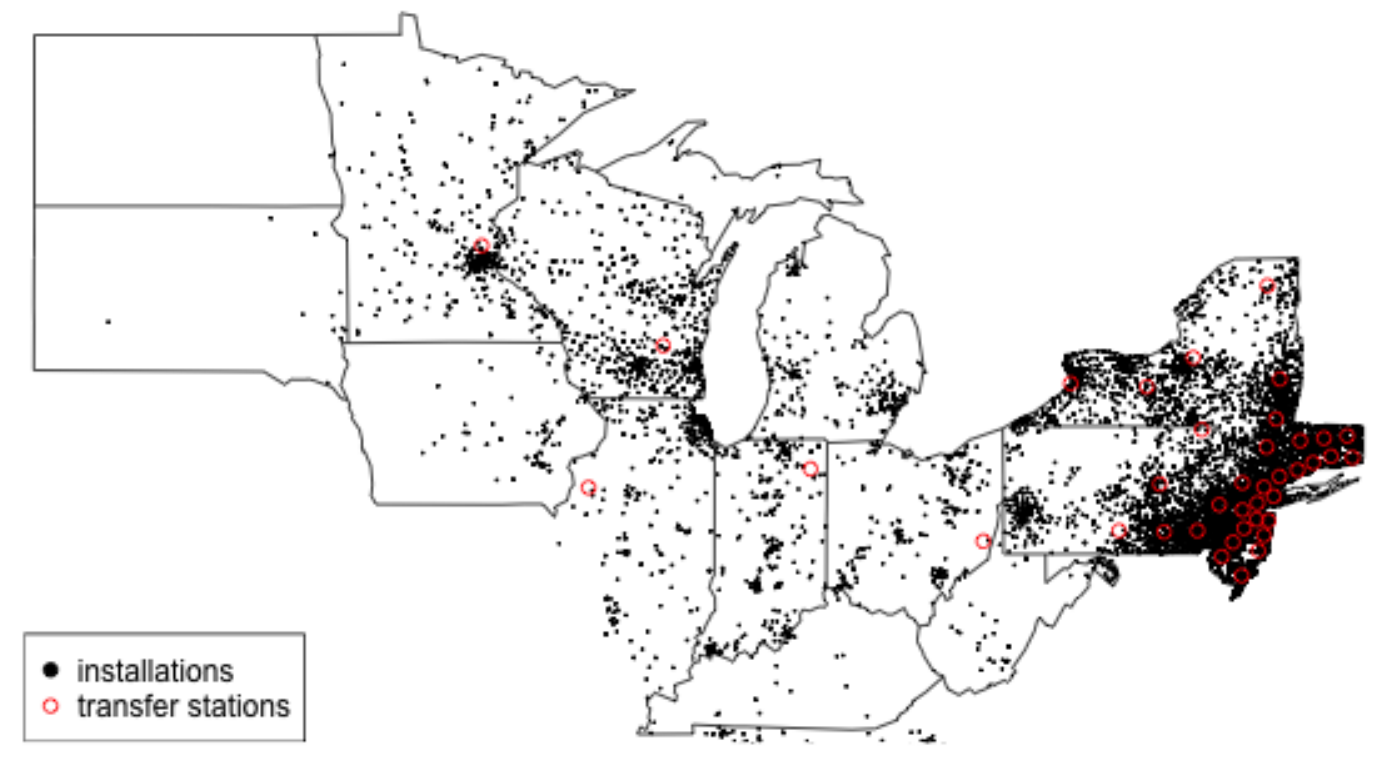

Figure 5. Installations, Transfer Stations and Landfill for Region 2

In the base case, all collected materials are landfilled. The materials are sent to one of several landfills, which is the closest in proximity to a transfer station. The average 
distance between stops along the collection route (i.e. waste source, transfer station, landfill) varies by region (as shown in Table 6). For each trip, the second leg of the route (i.e. transfer station to landfill) is $9-55 \mathrm{~km}$ shorter on average than the first leg (i.e. source to transfer station). These results mirror the design of municipal waste systems for special wastes types. Special wastes include any category outside of municipal solid waste (MSW) such as hazardous, construction and demolition waste, etc. For these waste types, there are fewer transfer stations (than for MSW), most of which are located close to landfills. Therefore, special wastes may travel further than MSW on the first leg of its trip. transfer stations are more numerous. Landfills tend to be in remote areas. Despite relatively low distance per trip, the first leg has a total emissions $50 \%$ greater than the second leg. This is an effect of "economies of scale." The transfer station gathers a large mass of waste derived from multiple small deliveries. Once a critical mass is reached the whole can be transported in a high capacity truck. Therefore, the second leg of the route requires fewer trips, thereby also lower emissions. To reduce transport emissions of EoL solar PV municipalities can increase the number of transfer stations accepting solar PV wastes. In addition, schedule waste pickups to maximize the load per trip.

Several simplifications were assumed to arrive at these results. The spatial location of modules has been generalized over a $10 \mathrm{~km}$ distance, further resolution may change location and routes slightly. In addition, the module specifications for weight, efficiency, and peak power were used for crystalline silicon PV as that is the majority of currently deployed modules. However, the data analyzed in this study considered the location, capacity, and recycling energy of thin-film photovoltaics such as cadmium telluride, amorphous silicon and copper indium diselenide modules in addition. Results therefore are an average for the major module types and specific routes could change if a shift in majority module type were to occur.

Table 7. Emissions by Region for Exhaustive Recycling with 90\% recovery

\begin{tabular}{|l|l|l|l|l|l|}
\hline $\begin{array}{l}\text { All g CO} \\
\text { eq/kWh }\end{array}$ & Region 1 & Region 2 & Region 3 & Region 4 & Region 5 \\
\hline landfill & 0.17 & 0.36 & 0.35 & 0.33 & 0.01 \\
\hline transport & 0.32 & 0.26 & $<0.01$ & 0.04 & 0.03 \\
\hline recycling & 120.17 & 255.39 & 251.48 & 232.25 & 7.70 \\
\hline total & 120.65 & 256.01 & 251.84 & 232.61 & 7.74 \\
\hline
\end{tabular}

In the base case, recycling is a boundary constraint. As we loosen the constraint, MRFs recover less EoL material. Without this constraint waste materials are not recycled. This mirrors the results previous economic analysis for PV material recovery [16]. This suggests that landfilling has lower emissions impact than recycling. Previous literature generally agrees with this result as shown in Table 8 . The preference for landfilling is partially based on scope of the study and a lack of data. Past literature is uncertain as to whether landfilling PVs has harmful. However, recent work shows that landfilled solar modules may leach toxic metals such as cadmium and molybdenum $[9,10,12]$. If our scope were to include ecotoxicity, the impact of recycling may outweigh landfilling when ecotoxicity is weighed more heavily than climate impacts. These results may change when long-term impacts are accounted for. However, there is gap in literature on the 
long-term impacts of landfill leaching of solar modules especially when multiple meteorological conditions (e.g. wind speed, temperature) are considered.

Previous research has reported the lifecycle emissions of solar modules to be 67.5, 19-30 and 31-67 g- $\mathrm{CO}_{2}$ equivalent per kwh for CIGS, CdTe, and silicon-based modules respectively $[5,46,47,48]$. Each of these studies assume modules are landfilled. In comparison, our results show that from an emissions perspective, recycling at end-of-life is a non-trivial portion of life cycle energy. Our results indicate that EoL recycling accounts for $1-20 \%$ of current lifecycle emissions on a per $\mathrm{m} 2$ basis see Table 8 .

Table 8. Comparative Results of Life Cycle Emissions for Solar Modules

\begin{tabular}{|c|c|c|c|c|}
\hline Authors/years & $\begin{array}{l}\text { Module } \\
\text { type }\end{array}$ & $\begin{array}{l}\text { Lifecycle } \\
\text { (g-CO2- } \\
\text { eq/kWh) }\end{array}$ & $\begin{array}{l}\text { End-of-Life } \\
\text { (g-CO2- } \\
\text { eq/kWh) }\end{array}$ & Comments \\
\hline Ito 2009 & & $51-53$ & & $\begin{array}{l}600 \mathrm{~km} \text { disposal } \\
\text { roundtrip, no } \\
\text { recycling }\end{array}$ \\
\hline $\begin{array}{l}\text { Mason and } \\
\text { Fthenakis } 2006\end{array}$ & $\mathrm{CdTe}$ & & $\begin{array}{l}1 \mathrm{~kg} \mathrm{CO} 2- \\
\mathrm{eq} / \mathrm{m} 2\end{array}$ & $\begin{array}{l}160 \mathrm{~km} \text { by truck, } \\
\text { shred PV } \\
\text { components then } \\
\text { landfilled, } \\
\text { Germany }\end{array}$ \\
\hline Ito 2010 & $\mathrm{c}-\mathrm{Si}$ & $31-67$ & & $\begin{array}{l}200 \mathrm{~km} \text { distance } \\
\text { to TS and LF }\end{array}$ \\
\hline Held, Ilg 2011 & $\mathrm{c}-\mathrm{Si}$ & $\begin{array}{l}5.13 \mathrm{~kg} \mathrm{CO} 2- \\
\text { equ } / \mathrm{m} 2\end{array}$ & $\begin{array}{l}6.03 \mathrm{~kg} \mathrm{CO} 2- \\
\mathrm{equ} / \mathrm{m} 2\end{array}$ & $\begin{array}{l}\text { Germany, } \\
\text { recycling cells, } \\
\text { glass, }\end{array}$ \\
\hline Berger et al 2010 & $\mathrm{CdTe}$ & & $\begin{array}{l}413-752 \mathrm{~kg} \\
\mathrm{CO} 2-\text { equ/m2 }\end{array}$ & \\
\hline Alsema, 2006 & $\mathrm{c}-\mathrm{Si}$ & 45 & & No recycling \\
\hline This study & $\mathrm{c}-\mathrm{Si}$ & & $\begin{array}{l}7 \text { - } 256 \text { g-CO2- } \\
\text { equ/kWh }\end{array}$ & $\begin{array}{l}\text { Range } 0-100 \% \\
\text { recycling of } \\
\text { module and } \\
\text { mounts, distance } \\
\text { varies }\end{array}$ \\
\hline
\end{tabular}

Our results indicate the majority of end-of-life emissions are spent on the electricity spent during the recycling process. The dominance of electricity is also found for both siliconbased and CdTe modules recycling [46].

We estimate that the impact of efficiency and dematerialization depends on any changes in design, module weight, and material complexity. We would expect increases in dematerialization and efficiency to decrease emissions per kwh assuming all other factors are static. That is, a more efficient panel will generate more energy over the use phase of the module lifetime given the same location, weather conditions, and solar irradiation. For example, assuming all other factors are unchanged, one would expect the emissions 
per kwh to decrease by half when efficiency increases by $90 \%$. However the assumption that the module weight, compositional complexity, and module design will be static with efficiency change is not consistent with solar PV's history. As module efficiencies have increased the complexity of materials has increased [49]. Previous work has also found increasing product complexity (i.e. number of parts or materials) reduces its recyclability and recycling rate[50]. This means recycling processes for high efficiency modules maybe be more energy intensive and have lower recycling rates than low efficiency modules. The result would likely erase environmental benefits made by increases in efficiency due to increased environmental burden of material recovery.

Dematerialization has a similar result as efficiency increases. In this case there is a tradeoff between transport, recycling, and dematerialization for utility PV. The less material and module area required for the same power output, the fewer trips and lower transport emissions required. A lower transport burden increases importance of recycling energy and the centralization of recovery facilities. More centralization leads to greater distances traveled. Since the size of distributed PV are small and geographically dispersed, the number of trips do not change with dematerialization. However the transport capacity may be even more under-utilized.

Elimination of the frame for thin-films, and reduction in layer thickness for all technologies are typical dematerialization advances proposed in literature [51]. However, silicon-based PV, which retains the largest market share of PV, has decreased weight by less than $0.5 \mathrm{~kg}$ or $5 \%$ in 20 years. In contrast, automobiles have reduced weights by between $15-20 \%$ over the same time period[52]. Therefore, it is uncertain whether dematerialization is a thin-film phenomenon or whether it will expand to significantly reduce weight of silicon-based modules. When applied to the model, a 5\% dematerialization, and increase in efficiency to $24 \%$ yields a $3-8 \%$ increase in carbon equivalent emissions per $\mathrm{kWh}$, as shown in Table 9. As the module weight decreases, fewer materials need to be processed per $\mathrm{kWh}$. However, dematerialization is often accompanied by more complex material compositions. Sorting and recovering a more complex mix may be more energy intensive. In this way, dematerialization may present an even greater challenge to recycling emissions. Overall, larger reductions in weight are required to more significantly impact end-of-life emissions.

Table 9. Sensitivity of EoL Emissions to Dematerialization and Efficiency Gains

\begin{tabular}{|l|l|l|l|l|}
\hline $\begin{array}{l}\text { Reduction in Mass / } \\
\text { All } \mathrm{g} \mathrm{CO} 2 \mathrm{e} / \mathrm{kWh}\end{array}$ & $\begin{array}{l}\text { Module Mass } \\
(\mathrm{kg})\end{array}$ & eff $=20 \%$ & eff $=22 \%$ & eff $=24 \%$ \\
\hline $0 \%$ & 15.6 & $120.7 *$ & 137.3 & 123.9 \\
\hline $2 \%$ & 15.288 & 110.9 & 110.3 & 134.6 \\
\hline $5 \%$ & 14.82 & 132.3 & 130.3 & 126.1 \\
\hline Frameless & 15.4425 & 130.7 & 98.4 & 116.3 \\
\hline
\end{tabular}

*Base Case

In the base case, where all materials are sent to landfill, the optimal recovery network configuration is highly decentralized as shown in Fig 5. In each case landfills do not reach capacity. 
As the recycling rate increases from $0 \%$ to $30 \%$, the network remains decentralized. Many MRFs in this scenario are under utilized. Materials are allocated to minimize distance travelled. Recycling accounts for between $80-90 \%$ of total emissions depending on the Region. Regions where the electricity generation is more carbon intensive such as Region 2 and 3 have higher emissions from recycling on a per kWh basis. In Region 1 due to its large land area, installations are located farther from landfills. Greater distance from landfills increases the transport carbon emissions.

As the recycling rate increases from $30 \%$ to $100 \%$ the network becomes more centralized. The model seeks to reduce the system emissions by selecting MRFs in states with lower electricity emissions on a per kWh basis. For the case of region 1 , recycling occurs for $60 \%$ of materials in California as shown in Fig 5. The other MRFs outside of CA retain less than $15 \%$ of the total end-of-life materials. In order to reduce the impact of recovery processing locate MRFs in states with less carbon intensive energy generation such as CA, ID, ME, NH, NY and VT. Alternatively, avoid locating MRFs in states with higher carbon intensity electricity such as IN, KT, DC, WV, UT and WY.

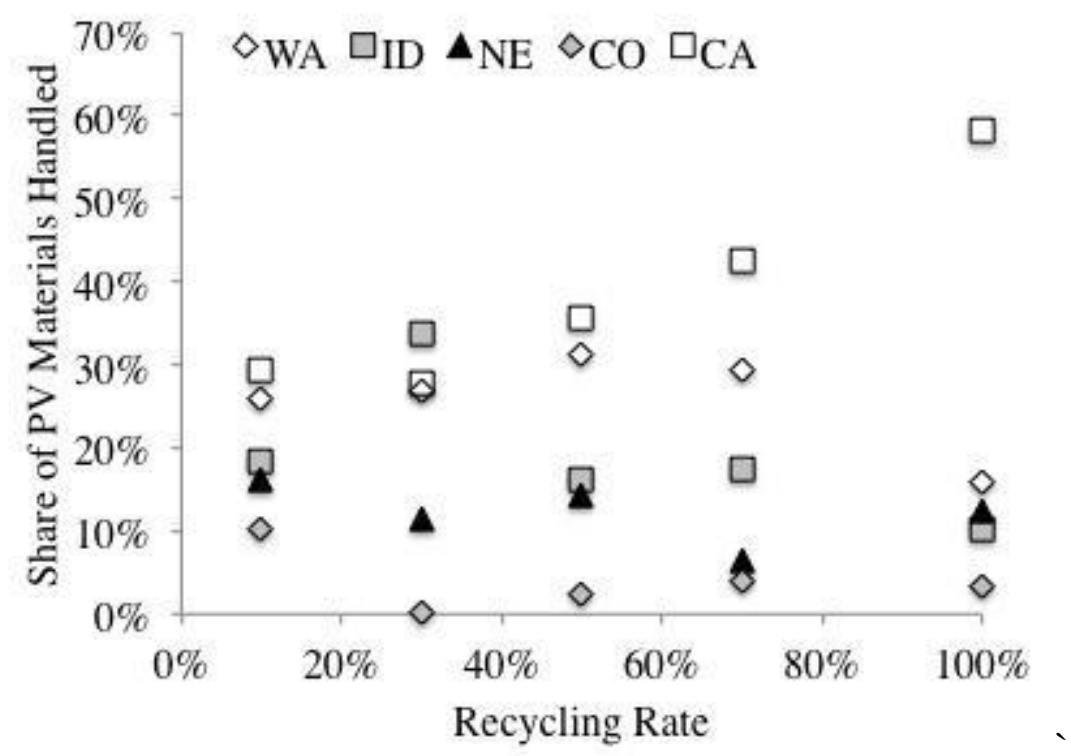

Figure 5. Share of Waste Materials by MRF Location and Recycling Rate in the South West Region

Sensitivity analysis highlights the various scenarios where smaller more fuel efficient vehicles reduce emissions in end-of-life phase for solar PV as shown in Table 10. As the fuel efficiency increases, the payload capacity decreases for transportation vehicles. Class 1t small pickup truck has the lowest carrying capacity considered. Although the small pickup truck is the most fuel efficient vehicle, it is only a better option than the dump truck for $100 \%$ recycling rate case. In the base case, we use the dump truck to transport materials to landfill. The dump truck is the best suited to transport materials to landfill in the no recycling case. As the recycling rate increases and waste is centralized in fewer facilities with lower emissions per $\mathrm{kWh}$, the dump truck becomes the worst option is terms of emissions per $\mathrm{kWh}$. The best option varies by recycling rate. For 40 to $100 \%$ 
recycling rate the delivery truck with 4-ton capacity has the least environmental impact. Between 0 and $40 \%$ there is tradeoff between emissions, miles per gallon, and payload capacity.

Table 10. Sensitivity End-of-Life Emission to Vehicle Type

\begin{tabular}{|l|l|l|l|l|}
\hline All $\mathrm{g}$ CO2 equ per $\mathrm{kWh}$ & $\mathrm{RR}=0 \%$ & $\mathrm{RR}=40 \%$ & $\mathrm{RR}=60 \%$ & $\mathrm{RR}=100 \%$ \\
\hline $1 \mathrm{t}:$ small pickup truck & 3.5 & 63.8 & 87.5 & 137.4 \\
\hline 2b $:$ large pickup & 2.9 & 59.3 & 93.23 & 133.6 \\
\hline 5: delivery truck & 2.5 & 43.9 & 80.4 & 133.1 \\
\hline 8b $:$ dump Truck & 2.2 & 55.3 & 82.8 & 149.3 \\
\hline
\end{tabular}

Vehicle type also has a large impact on network configuration and collection. The use of heavy-duty vehicles may not be necessary for each trip as the vehicle capacity will be under utilized. However, in the case of large installations a larger capacity vehicle reduces trips and overall environmental impact. Although this may oversimplify reality since panels will likely reach EoL at different times and it may be unlikely for more than $5 \mathrm{~kW}$ of product to be transported to collection a facility at one time.

Other improvements to solar PV system overall have the potential to reduce recycling energy and related environmental impacts. For example, recycling of the balance of the system beyond mounting components, which was not explored in this study. Previous work suggests BOS recycling can reduce thin-film lifecycle emissions by 7-8\% [51,53].

In order to characterize the sensitivity of the model to base case assumptions we have varied several input parameters. Increasing the vehicle capacity allows for the transport of more modules per trip. However, the upper limit of vehicle capacity depends on the flow materials to transfer stations. Currently, we estimate less than 17 tons of solar materials reaches end-of-life per day over the next 20 years in the US. This EoL material is dispersed so that one state could see 0.1-1.1 tons per day. This requires over 30-300 days inventory to fill a 30-ton lorry. Transfer stations typically turn over waste at least once a week. Therefore, it may not be realistic to increase vehicle capacity beyond 10-ton lorry due to low demand.

Different collection schemes can also be applied to large ( $>50 \mathrm{~kW})$ and distributed $(<10 \mathrm{~kW})$ installations. Separate EoL collection and recycling schemes for large utility and distributed residential installations have been suggested by previous authors (Choi and Fthenakis, 2014). The larger the installation, the more end-of-life materials can be efficiently transported. The environmental impact of collection and recovery of utility is slightly lower than distributed installations despite the farther distances from landfills.

\section{Conclusions}


In this paper we have explored the environmental tradeoffs of transporting, landfill processing, and recycling end-of-life solar PV. We developed a model that combines a discrete waste network with GIS tools. This is a novel approach that can be applied to a variety of geographic locations and waste streams. The model is applied to a case study of the lower 48 states. This area of the U.S. has experienced greater solar adoption in the last 18 months than in the previous 20 years. The majority of U.S. capacity is utility, large installations greater than $1 \mathrm{MW}$ that are co-located.

For the case study, the results indicate that when states trade in solar PV waste the environmental impact depends on the geographic dispersion, emission factors of electricity, and the proportion of utility installations. Those regions with greater distributed solar installations, in general, require a greater number of trips, and therefore greater environmental impact per $\mathrm{kWh}$. Also, the higher the emission factors the greater than environmental impact of recycling activities. As we increase the recycling rate, the network configuration changes from decentralized to centralized. the model seeks to reduce total system emissions by sending recycled materials to facilities with the lowest emissions factors. There is a tradeoff between transport distance and recycling energy. That is, as recycling rate increases transport distance becomes less important than recycling energy. From this perspective, end-of-life material recovery facilities should be established in states with low carbon emission factors (i.e. high renewable energy adoption) such as California, Oregon, Washington, Vermont, Maine, and Idaho.

We estimate that efficiency and dematerialization will have a negative impact on end-oflife emissions. Dematerialization will increase emissions due to transport, recycling, and landfill processing by $5-36 \%$, This occurs because smaller module area (i.e. few materials) are required to produce the same power output.

Regions may benefit from high clustering of distributed solar PV in mid to large cities which reduces the transport distance to potential transfer stations. However, because the share of distributed PV is declining and the capacity is small (compared to utility) it doesn't make much sense to pursue high recycling rates for distributed PV. Instead our results indicate, locating material recovery facilities near utility PV makes the most sense from an end-of-life emissions perspective.

Despite the previously discussed toxicity concerns with landfilling, our study suggest that states trade in PV waste trade like other waste. Waste collectors may have take special care when dealing with broken modules. The U.S. MSW system may develop standards specifically for handling PV waste as hazardous similar to the European Union under the WEEE Directive [54] .

Although we attempt to capture many of the important aspects of solar PV infrastructure recovery there are several impacts not explored. Some of these implications, such as emissions from processing and social implications of transportation infrastructure siting on vulnerable populations are those common to most waste processing infrastructure, while others such as human health issues related to dust or landfilled waste use may be unique to $\mathrm{PV}$ processing. 
Future work in this area may also include evaluating the influence of disruptive shifts in adoption such as new zoning, location specific legislation or incentives on waste network configuration and end-of-life environmental impacts.

\section{Acknowledgements}

This work has been supported by the National Science Foundation (NSF) through award CBET \#1454166. Thank you to Dr. Brian Tomaszewski for his assistance in developing the geo-spatial model used as a foundation for this work. The authors would also like to acknowledge the Golisano Institute for Sustainability at Rochester Institute of Technology (RIT) for continued financial support for student and faculty authors as well as access to facilities and scholarly resources, including Simapro 8, the ecoinvent database, and ESRI ArcGIS.

\section{References}

[1] M. Goe, G. Gaustad, Identifying critical materials for photovoltaics in the US: A multi-metric approach, Applied Energy. $123 \quad$ (2014) 387-396. doi:10.1016/j.apenergy.2014.01.025.

[2] N. T. Nassar, R. Barr, M. Browning, Z. Diao, E. Friedlander, E. M. Harper, C. Henly, G. Kavlak, S. Kwatra, C. Jun, S. Warren, M.-Y. Yang, and T. E. Graedel, "Criticality of the Geological Copper Family," Environmental Science \&amp; Technology Environ. Sci. Technol., vol. 46, no. 2, pp. 1071-1078, 2012.

[3] PV Cycle ORG, PV Cycle ORG. (n.d.). http://www.pvcycle.org/about/ (accessed December 4, 2015).

[4] M. Goe, G. Gaustad, Strengthening the case for recycling photovoltaics: An energy payback analysis, Applied Energy. $120 \quad$ (2014) 41-48. doi:10.1016/j.apenergy.2014.01.036.

[5] J. Peng, L. Lu, H. Yang, Review on life cycle assessment of energy payback and greenhouse gas emission of solar photovoltaic systems, Renewable And Sustainable Energy Reviews. 19 (2013) 255-274. doi:10.1016/j.rser.2012.11.035.

[6] Solar Market Insight Report 2015 Q2, SEIA. (n.d.). http://www.seia.org/researchresources/solar-market-insight-report-2015-q2 (accessed December 4, 2015).

[7] V.M. Fthenakis, P.D. Moskowitz, Thin-film Photovoltaic Cells: Health and Environmental Issues in their Manufacture Use and Disposal, Prog. Photovolt: Res. Appl. Progress In Photovoltaics: Research and Applications. 3 (1995) 295-306. doi:10.1002/pip.4670030504. 
[8] V.M. Fthenakis, M. Fuhrmann, J. Heiser, A. Lanzirotti, J. Fitts, W. Wang, Emissions and encapsulation of cadmium in CdTe PV modules during fires, Prog. Photovolt: Res. Appl. Progress In Photovoltaics: Research and Applications. 13 (2005) 713-723. doi:10.1002/pip.624.

[9] M. Patterson, A. Turner, M. Sadeghi, R. Marshall, Health, safety and environmental aspects of the use of cadmium compounds in thin film PV modules, Solar Energy Materials And Solar Cells. 35 (1994) 305-310. doi:10.1016/0927-0248(94)90155-4.

[10] P. Sinha, Cadmium telluride leaching behavior: Discussion of Zeng et al. (2015), Journal Of Environmental Management. $163 \quad$ (2015) 184-185. doi:10.1016/j.jenvman.2015.08.015.

[11]Y.-S. Zimmermann, C. Niewersch, M. Lenz, Z.Z. Kül, P.F.-X. Corvini, A. Schäffer, et al., Recycling of Indium From CIGS Photovoltaic Cells: Potential of Combining AcidResistant Nanofiltration with Liquid-Liquid Extraction, Environmental Science \&Amp; Technology Environ. Sci. Technol. 48 (2014) 13412-13418. doi:10.1021/es502695k.

[12] Y.-S. Zimmermann, A. Schäffer, P.F.-X. Corvini, M. Lenz, Thin-Film Photovoltaic Cells: Long-Term Metal(loid) Leaching at Their End-of-Life, Environmental Science \&Amp; Technology Environ. Sci. Technol. 47 (2013) 13151-13159. doi:10.1021/es402969c.

[13] A. Finke, A. Kriele, W. Thumm, D. Bieniek, A. Kettrup, Leaching tests with thin film solar cells based on copper indium diselenide (CIS), Chemosphere. 32 (1996) 16331641. doi:10.1016/0045-6535(96)00073-2.

[14] J.-K. Choi, V. Fthenakis, Economic Feasibility of Recycling Photovoltaic Modules, Journal Of Industrial Ecology. 14 (2010) 947-964. doi:10.1111/j.15309290.2010.00289.x.

[15] J.-K. Choi, V. Fthenakis, Crystalline silicon photovoltaic recycling planning: macro and micro perspectives, Journal Of Cleaner Production. 66 (2014) 443-449. doi:10.1016/j.jclepro.2013.11.022.

[16]M. Goe, G. Gaustad, B. Tomaszewski, System tradeoffs in siting a solar photovoltaic material recovery infrastructure, Journal Of Environmental Management. 160 (2015) 154-166. doi:10.1016/j.jenvman.2015.05.038.

[17] O.B. Delgado, M. Mendoza, E.L. Granados, D. Geneletti, Analysis of land suitability for the siting of inter-municipal landfills in the Cuitzeo Lake Basin, Mexico, Waste Management. 28 (2008) 1137-1146. doi:10.1016/j.wasman.2007.07.002.

[18] M. Ekmekçioğlu, T. Kaya, C. Kahraman, Fuzzy multicriteria disposal method and site selection for municipal solid waste, Waste Management. 30 (2010) 1729-1736. doi:10.1016/j.wasman.2010.02.031.

[19] P.V. Gorsevski, K.R. Donevska, C.D. Mitrovski, J.P. Frizado, Integrating multicriteria evaluation techniques with geographic information systems for landfill site 
selection: A case study using ordered weighted average, Waste Management. 32 (2012) 287-296. doi:10.1016/j.wasman.2011.09.023.

[20] M. Sharifi, M. Hadidi, E. Vessali, P. Mosstafakhani, K. Taheri, S. Shahoie, et al., Integrating multi-criteria decision analysis for a GIS-based hazardous waste landfill sitting in Kurdistan Province, western Iran, Waste Management. 29 (2009) 2740-2758. doi:10.1016/j.wasman.2009.04.010.

[21]V. Sumathi, U. Natesan, C. Sarkar, GIS-based approach for optimized siting of municipal solid waste landfill, Waste Management. 28 (2008) 2146-2160. doi:10.1016/j.wasman.2007.09.032.

[22] M.K. Korucu, A. Karademir, Siting a municipal solid waste disposal facility, Part II: The effects of external criteria on the final decision, Journal Of the Air \&Amp; Waste Management Association. 64 (2014) 131-140. doi:10.1080/10962247.2013.809388.

[23] McCarthy, J. E. (2007). CRS Report for Congress: Interstate Shipment of Municipal Solid Waste: 2007 Update, 1-30.

[24] Environmental Protection Agency (E.P.A.). "List of Municipal Solid Waste Landfills" Report No. 530-R96-006, 1996.

[25] Photon International, Module Database. February 2015 pp. 131-170

[26]GREET, The Greenhouse Gases, Regulated Emissions, and Energy Use In Transportation Model, GREET 1.8d.1, developed by Argonne National Laboratory, Argonne, IL, released August 26, 2010. http://greet.es.anl.gov/

[27] U.S. Environmental Protection Agency. Inventory of U.S. Greenhouse Gas Emissions and Sinks: 1990-2005, EPA 430-R-07-002, Annex 3.2, (April 2007), web site: http://www.epa.gov/climatechange/emissions/usinventoryreport.html.

[28] The National Academies, Technologies and Approaches to Reducing the Fuel Consumption of Medium- and Heavy-Duty Vehicles, 2010.

[29] International Energy Agency Solar Technology Roadmap, 2014

[30] U.S. Energy Information Administration Annual Energy Outlook, 2015

[31] U.S. Energy Information Administration International Energy Outlook 2013

[32] M.A. Green, K. Emery, Y. Hishikawa, W. Warta, E.D. Dunlop, Solar cell efficiency tables (version 43), Prog. Photovolt: Res. Appl. Progress In Photovoltaics: Research and Applications. 22 (2013) 1-9. doi:10.1002/pip.2452.

[33] The Open PV Project, The Open PV Project. (n.d.). https://openpv.nrel.gov/index (accessed December 4, 2015).

[34] G. A. Keoleian, K. Kar, M. M. Manion, J. W. Bulkley, Industrial Ecology of the Automobile: A Life Cycle Perspective, Society of Automotive Engineers, Inc., Warrendale, PA, 1997, p. 148. 
[35] M. Ito, K. Kato, K. Komoto, T. Kichimi, K. Kurokawa, A comparative study on cost and life-cycle analysis for $100 \mathrm{MW}$ very large-scale PV (VLS-PV) systems in deserts using $\mathrm{m}-\mathrm{Si}$, a-Si, CdTe, and CIS modules, Prog. Photovolt: Res. Appl. Progress In Photovoltaics: Research and Applications. 16 (2007) 17-30. doi:10.1002/pip.770.

[36] J.E. Mason, V.M. Fthenakis, T. Hansen, H.C. Kim, Energy payback and life-cycle CO2 emissions of the BOS in an optimized 3.5 MW PV installation, Prog. Photovolt: Res. Appl. Progress In Photovoltaics: Research and Applications. 14 (2006) 179-190. doi:10.1002/pip.652.

[37] Energy Information Administration, Updated State-and Regional-level Greenhouse Gas Emission Factors for Electricity (March 2002)

[38] Frischknecht, R. (2010). LCI modelling approaches applied on recycling of materials in view of environmental sustainability, risk perception and ecoefficiency. The International Journal of Life Cycle Assessment, 15(7), 666-671. http://doi.org/10.1007/s11367-010-0201-6

[39] W. Berger, F.-G. Simon, K. Weimann, E.A. Alsema, A novel approach for the recycling of thin film photovoltaic modules, Resources, Conservation And Recycling. 54 (2010) 711-718. doi:10.1016/j.resconrec.2009.12.001.

[40] Nishimura, A., Hayashi, Y., Tanaka, K., Hirota, M., Kato, S., Ito, M., et al. (2010). Life cycle assessment and evaluation of energy payback time on high-concentration photovoltaic power generation system. Applied Energy, 87(9), 2797-2807. http://doi.org/10.1016/j.apenergy.2009.08.011

[41] Tsoutsos, Theocharis, Niki Frantzeskaki, and Vassilis Gekas. "Environmental impacts from the solar energy technologies." Energy Policy 33.3 (2005): 289-296.

[42] D. Noll, C. Dawes, V. Rai, Solar Community Organizations and active peer effects in the adoption of residential PV, Energy Policy. 67 (2014) 330-343. doi:10.1016/j.enpol.2013.12.050.

[43] Robinson, S. A., Stringer, M., Rai, V., \& Tondon, A. (2013). GIS-Integrated AgentBased Model of Residential Solar PV Diffusion. Presented at the 32nd United States Association of Energy Economics (USAEE)/ International Association of Energy Economics (ISEE) North American Conference, Anchorage.

[44] V. Rai, B. Sigrin, Diffusion of environmentally-friendly energy technologies: buy versus lease differences in residential PV markets, Environ. Res. Lett. Environmental Research Letters. 8 (2013) 014022. doi:10.1088/1748-9326/8/1/014022.

[45] K. Siler-Evans, I.L. Azevedo, M.G. Morgan, J. Apt, Regional variations in the health, environmental, and climate benefits of wind and solar generation, Proceedings Of the National Academy of Sciences. 110 (2013) 11768-11773. doi:10.1073/pnas.1221978110. 
[46] M. Held, R. Ilg, Update of environmental indicators and energy payback time of CdTe PV systems in Europe, Prog. Photovolt: Res. Appl. Progress In Photovoltaics: Research and Applications. 19 (2011) 614-626. doi:10.1002/pip.1068.

[47] M. Ito, K. Komoto, K. Kurokawa, A comparative LCA study on potential of verylarge scale PV systems in Gobi desert, 2009 34th IEEE Photovoltaic Specialists Conference (PVSC). (2009). doi:10.1109/pvsc.2009.5411180.

[48] M. Ito, M. Kudo, M. Nagura, K. Kurokawa, A comparative study on life cycle analysis of 20 different PV modules installed at the Hokuto mega-solar plant, Prog. Photovolt: Res. Appl. Progress In Photovoltaics: Research and Applications. 19 (2011) 878-886. doi:10.1002/pip.1070.

[49] Green, Martin A., et al. "Solar cell efficiency tables (Version 45)." Progress in photovoltaics: research and applications 23.1 (2015): 1-9.

[50] Dahmus, J. B., \& Gutowski, T. G. What Gets Recycled: An Information Theory Based Model for Product Recycling. Environmental Science \& Technology, 41(21), (2007), 75437550. http://doi.org/10.1021/es062254b

[51] J.D. Bergesen, G.A. Heath, T. Gibon, S. Suh, Thin-Film Photovoltaic Power Generation Offers Decreasing Greenhouse Gas Emissions and Increasing Environmental Co-benefits in the Long Term, Environmental Science \&Amp; Technology Environ. Sci. Technol. 48 (2014) 9834-9843. doi:10.1021/es405539z.

[52] A. Bandivadekar, On the road in 2035: reducing transportation's petroleum consumption and GHG emissions, Massachusetts Institute of Technology, Cambridge, MA, 2008.

[53] D. Ravikumar, P. Sinha, T.P. Seager, M.P. Fraser, An anticipatory approach to quantify energetics of recycling CdTe photovoltaic systems, Prog. Photovolt: Res. Appl. Progress In Photovoltaics: Research and Applications. (2015). doi:10.1002/pip.2711.

[54] European Parliament and of the Council, 2003. On Waste Electrical and Electronic Equipment (WEEE). 